\title{
Labedella gwakjiensis gen. nov., sp. nov., a novel actinomycete of the family Microbacteriaceae
}

\author{
Soon Dong Lee
}

Correspondence

Soon Dong Lee

sdlee@cheju.ac.kr
Department of Science Education, Cheju National University, Jeju 690-756, Republic of Korea
A Gram-positive, non-motile, non-mycelium-forming, rod-shaped actinomycete, designated $\mathrm{KSW} 2-17^{\top}$, was isolated from dried seaweed collected from beach sand along the coast of Jeju, Republic of Korea. The organism had ornithine as the diagnostic cell-wall diamino acid, MK-10 and MK-11 as the major menaquinones, and phosphatidylglycerol and diphosphatidylglycerol as polar lipids. The fatty acid profile included predominantly iso- and anteiso-branched acids and a minor amount of tuberculostearic acid (10-methyl $\mathrm{C}_{18: 0}$ ). The DNA $\mathrm{G}+\mathrm{C}$ content was $68.0 \mathrm{~mol} \%$. Phylogenetic analysis based on 16S rRNA gene sequences showed that the seaweed isolate formed a distinct clade within the radiation of the family Microbacteriaceae and had highest sequence similarity (96.1-96.3\%) to members of the genera Cryobacterium, Frigoribacterium and Rathayibacter. On the basis of phenotypic and genotypic evidence, strain KSW2 $-17^{\top}$ is considered to represent a novel species of a new genus, for which the name Labedella gwakjiensis gen. nov., sp. nov. is proposed. The type strain is KSW2-17 ${ }^{\top}$ (=JCM $14008^{\top}=$ KCTC $19176^{\top}$ ).
The family Microbacteriaceae (Park et al., 1993; Stackebrandt et al., 1997) embraces a large group of rod-shaped or rarely coccoid or mycelium-forming actinobacteria that have Btype cell-wall peptidoglycan and unsaturated menaquinones. At the time of writing, the family comprises 20 genera with validly published names, including the recently described genera Gulosibacter, Pseudoclavibacter (Manaia et al., 2004) and Microcella (Tiago et al., 2005). The genera of the family can be readily differentiated on the basis of chemotaxonomic characters, such as diagnostic diamino acids of the cell-wall peptidoglycan (ornithine, lysine, 2,4diaminobutyric acid), peptidoglycan type, major menaquinones and cellular fatty acid composition. Members of the family occur in diverse environments, including seawater and marine mud (Evtushenko \& Takeuchi, 2003; Han et al., 2003). In this paper, we describe an actinomycete isolated from seaweed, which represents a novel species of a new genus within the family Microbacteriaceae.

Strain KSW2-17 $7^{\mathrm{T}}$ was isolated from a dried seaweed sample collected at Gwakji Beach in Jeju, Republic of Korea, during a study of exopolysaccharide-producing marine bacteria. A piece of dried seaweed was transferred directly onto a WAT-SW agar plate (Lee, 2006). One colony on the plate, incubated at $30{ }^{\circ} \mathrm{C}$ for 14 days, was subcultured onto TSA-SW medium [trypticase soy agar (TSA; Difco) in a mixture of $60 \%(\mathrm{v} / \mathrm{v})$ natural seawater and $40 \%(\mathrm{v} / \mathrm{v})$ distilled water]. The pure culture was maintained in $20 \%$ glycerol suspension supplemented with $60 \%$ natural

The GenBank/EMBL/DDBJ accession number for the 16S rRNA gene sequence of strain $\mathrm{KSW} 2-17^{\top}$ is D0533552. seawater at -20 and $-80{ }^{\circ} \mathrm{C}$. Strain KSW2- $17^{\mathrm{T}}$ showed good growth on YE-SW medium [ISP 2 medium (Shirling \& Gottlieb, 1966) supplemented with $60 \%$ (v/v) seawater], TSA and nutrient agar (NA; Difco), but moderate growth on NA-SW (NA plus seawater), marine agar (MA; Difco) and ISP 2 medium.

Cell morphology was observed via phase-contrast and electron microscopy with cells grown on TSA for 6, 15, 24 and $72 \mathrm{~h}$. For scanning electron microscopy, cells were fixed with $1 \%(\mathrm{w} / \mathrm{v})$ osmium tetroxide for $1 \mathrm{~h}$, dehydrated through a graded ethanol series and substituted with isoamyl acetate. After critical-point drying in $\mathrm{CO}_{2}$, the samples were coated with gold and observed by using a scanning electron microscope (model S-2460; Hitachi). Cell motility was tested by monitoring the degree of turbidity on motility test medium $(0.3 \%$ beef extract, $1.0 \%$ peptone, $0.5 \% \mathrm{NaCl}$ and $0.4 \%$ Bacto agar) as described by Mac Faddin (1980) and by phase-contrast microscopy. Colony pigmentation and morphology were observed with cultures grown on TSA at $30{ }^{\circ} \mathrm{C}$ for 5 days. Oxidase and catalase activities were determined with solutions of $1 \%(\mathrm{w} / \mathrm{v})$ tetramethyl-p-phenylenediamine and $3 \%(\mathrm{v} / \mathrm{v}) \mathrm{H}_{2} \mathrm{O}_{2}$, respectively. For these tests, cells were grown on TSA at $30{ }^{\circ} \mathrm{C}$ for $48 \mathrm{~h}$. $\beta$-Galactosidase activity was determined by using the method described by Gosink et al. (1998). Gram stain, hydrolysis of aesculin, elastin and starch, reduction of nitrate, and production of $\mathrm{H}_{2} \mathrm{~S}$ were investigated according to the methods described by Mac Faddin (1980). Growth temperature was determined on TSA at $4-45^{\circ} \mathrm{C}$. $\mathrm{NaCl}$ tolerance for growth was tested on TSA supplemented with $1-9 \%(\mathrm{w} / \mathrm{v}) \mathrm{NaCl}$. The $\mathrm{pH}$ range 
(4.1-10.1) for growth was determined on TSA with $\mathrm{pH}$ adjustment at intervals of $1.0 \mathrm{pH}$ unit. Production of acid from carbohydrates and alcohols was determined on Bacto OF basal medium (Difco) supplemented with filtersterilized carbon source at a final concentration of $1 \%$ $(\mathrm{w} / \mathrm{v})$. Cells were grown in trypticase soy broth (TSB; Difco) at $30{ }^{\circ} \mathrm{C}$ for 2 days and harvested by centrifugation. After washing out with distilled water, the cells were used as inoculum sources for the utilization of carbon sources. The agar plates were incubated at $30{ }^{\circ} \mathrm{C}$ for 14 days under aerobic conditions. Urease activity was determined by monitoring a colour change in Bacto urea broth (Difco). DNA hydrolysis was determined by using DNase test agar (Difco) supplemented with methyl green. Other physiological and biochemical properties were tested by using API $20 \mathrm{NE}$ and API ZYM strips according to the manufacturer's instructions (bioMérieux), with cells grown on TSA at $30{ }^{\circ} \mathrm{C}$ for 2 days. Cells of strain KSW2 $-17^{\mathrm{T}}$ were Grampositive, aerobic, non-spore-forming, non-myceliumforming, non-motile rods (Fig. 1). The results of phenotypic characterization tests are given in the genus and species descriptions below.

Chromosomal DNA was extracted and purified according to the method of Hopwood et al. (1985). The DNA G+C content of strain KSW2-17 $17^{\mathrm{T}}$ was determined with HPLC as described by Mesbah et al. (1989). The base composition of strain KSW2-17 $7^{\mathrm{T}}$ was $68.0 \mathrm{~mol} \%$. The $16 \mathrm{~S}$ rRNA gene of strain KSW2-17 ${ }^{\mathrm{T}}$ was amplified by PCR and directly sequenced as described by Lee (2006). The CLUSTAL_X software (Thompson et al., 1997) was used for multiple alignments of sequences. Phylogenetic analyses were performed using three tree-making algorithms, namely the neighbour-joining (Saitou \& Nei, 1987), maximumlikelihood (Felsenstein, 1981) and maximum-parsimony (Fitch, 1971) methods. A neighbour-joining tree was constructed from evolutionary distances calculated by the

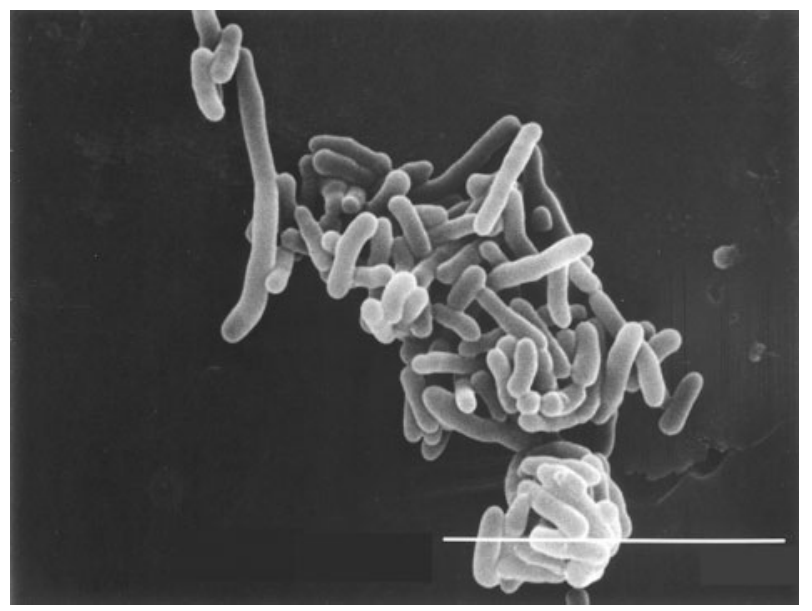

Fig. 1. Scanning electron micrograph of cells of strain KSW2-17 grown on TSA for 3 days at $30{ }^{\circ} \mathrm{C}$. Bar, $5 \mu \mathrm{m}$. method described by Jukes \& Cantor (1969). Tree topology was evaluated by bootstrap analysis (Felsenstein, 1985) of the neighbour-joining data set, based on 1000 replications.

In the neighbour-joining tree (Fig. 2) based on $16 \mathrm{~S}$ rRNA gene sequences, strain KSW2-17 $7^{\mathrm{T}}$ formed a distinct clade within the radiation of the family Microbacteriaceae, with Cryobacterium psychrophilum as its closest neighbour. This relationship was supported by a high bootstrap value $(78 \%)$ and was also found in trees obtained when other tree-making algorithms were applied. Highest 16S rRNA gene sequence similarity was with the type strains of Cryobacterium psychrophilum and Frigoribacterium faeni (96.3\%), followed by Rathayibacter tritici (96.2\%) and Rathayibacter rathayi (96.1\%). Sequence similarities with other members of the family Microbacteriaceae were in the range $91.3-95.9 \%$.

Cell biomass for chemical analyses was obtained from cultures grown in TSB for 3 days at $30{ }^{\circ} \mathrm{C}$ with shaking. For determining the amino acid composition in the peptidoglycan, cells were ground with aluminium oxide. Purified cell wall was obtained according to the method of Hancock (1994) as follows: cell-wall preparations were mixed in boiling SDS with continuous stirring for $30 \mathrm{~min}$. After harvesting by centrifugation, this treatment was repeated several times until all extractable UV-absorbing material was removed. Finally, sample material was treated with proteinase $\mathrm{K}$ (Sigma), recovered by centrifugation and washed four times with water. Hydrolysis of purified cell wall was carried out by using $4 \mathrm{M} \mathrm{HCl}$ at $100{ }^{\circ} \mathrm{C}$ for $16 \mathrm{~h}$. Quantitative determination of amino acids was performed by reversed-phase HPLC (2690, Waters) of the derivatized amino acid with AccQFluor Reagent (Waters) according to the manufacturer's instructions. The acyl type of the peptidoglycan was analysed according to the method of Uchida \& Aida (1984). Polar lipids and menaquinones were extracted by the integrated procedure of Minnikin et al. (1984). The purified menaquinones were identified by HPLC as described by Kroppenstedt (1985). The phospholipid composition was determined according to the method of Minnikin et al. (1977). Analysis of cellular fatty acids was performed by using GC according to the instructions of the Sherlock Microbial Identification System (version 6; MIDI), with cells grown on TSA for 3 days at $30{ }^{\circ} \mathrm{C}$.

Purified peptidoglycan of strain KSW2- $17^{\mathrm{T}}$ contained ornithine as the diagnostic diamino acid. The molar ratio of alanine/glycine/glutamic acid/ornithine was estimated to be $0.9: 1.1: 1.0: 1.1$. Homoserine and other amino acids were not detected. The polar lipid profile contained phosphatidylglycerol and diphosphatidylglycerol. Glycolipids or other phospholipids, namely phosphatidylcholine and ninhydrinpositive phospholipids, were not detected. The major menaquinones were MK-10 (44\%) and MK-11 (31\%), with lesser amounts of MK-9 and MK-7. The major fatty acids were anteiso- $\mathrm{C}_{15: 0}(49.4 \%)$, iso- $\mathrm{C}_{16: 0}(20.5 \%)$ and anteiso$\mathrm{C}_{17: 0}(11.4 \%)$. Minor components included $\mathrm{C}_{16: 0}(5.8 \%)$, 


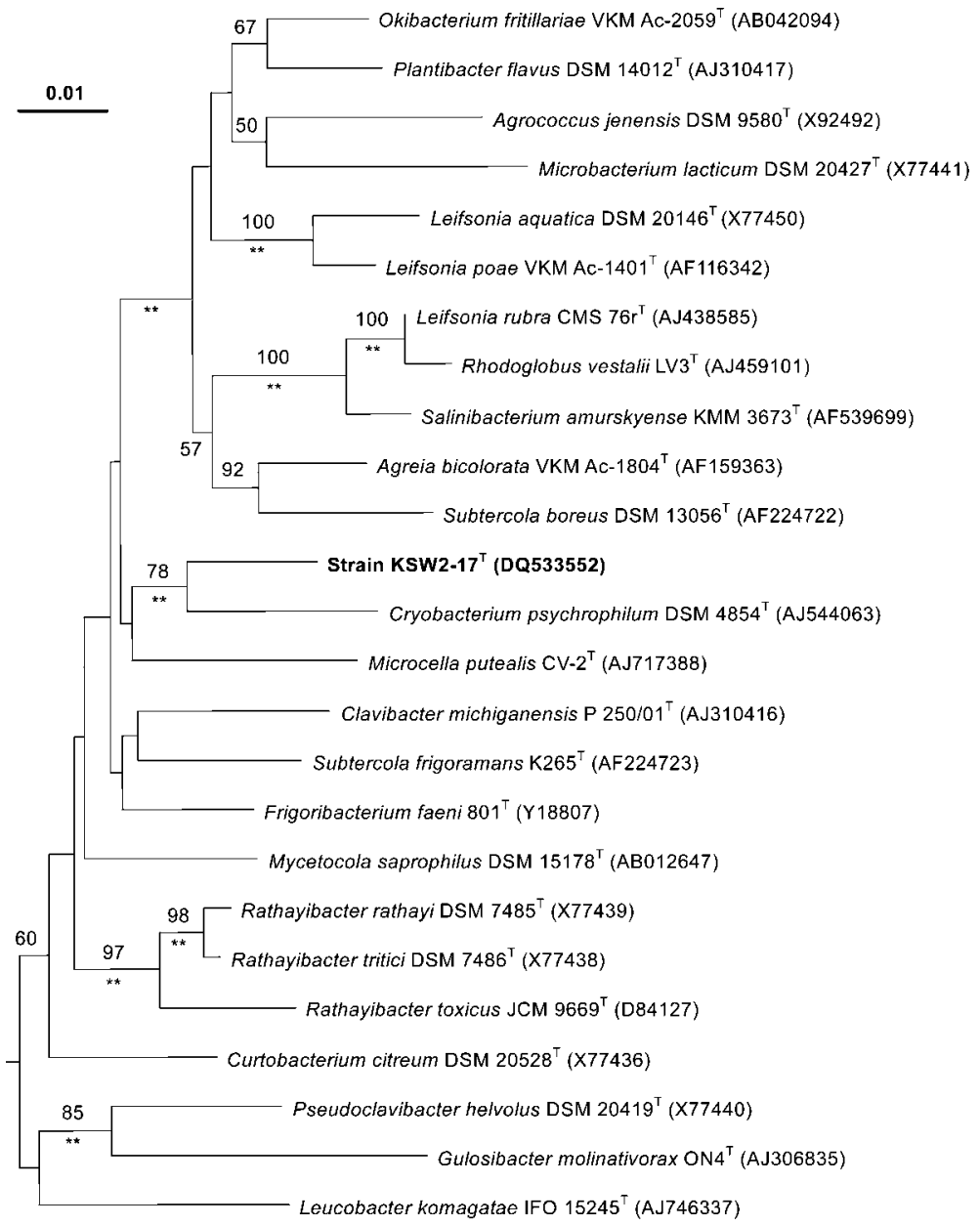

Fig. 2. Neighbour-joining tree showing the phylogenetic position of strain $\mathrm{KSW} 2-17^{\top}$ within the family Microbacteriaceae. Micrococcus luteus DSM 20030' (AJ536198) was used as outgroup taxon (not shown). Double asterisks indicate the corresponding branches that were also found in both maximum-likelihood and maximum-parsimony trees. Numbers at the branches indicate bootstrap support values, based on 1000 replications (only values above $50 \%$ are shown). Bar, 0.01 substitutions per nucleotide position.

$\mathrm{C}_{18: 0}(1.7 \%)$, iso- $\mathrm{C}_{14: 0}(2.0 \%)$, iso- $\mathrm{C}_{15: 0}(2.0 \%), \mathrm{C}_{18: 1} \omega 9 c$ (1.8\%), 10-methyl $\mathrm{C}_{18: 0}$ (tuberculostearic acid, $1.8 \%$ ) and a mixture of iso- $\mathrm{C}_{15: 0} 2-\mathrm{OH}$ and/or $\mathrm{C}_{16: 1} \omega 7 c(1.6 \%)$. The presence of tuberculostearic acid is noteworthy given that this component has not previously been found in representatives of the family Microbacteriaceae.

The data obtained show that strain KSW2-17 $7^{\mathrm{T}}$ is clearly distinguishable phenotypically from its closest phylogenetic relative, Cryobacterium psychrophilum, which is psychrophilic (optimum growth temperatures of $9-12^{\circ} \mathrm{C}$; no growth at $18{ }^{\circ} \mathrm{C}$ ) and has the cell-wall peptidoglycan based upon 2,4-diaminobutyric acid (Suzuki et al., 1997; Inoue and Komagata, 1976). Among the other bacteria sharing relatively high $16 \mathrm{~S}$ rRNA gene sequence similarity to strain KSW2-17 ${ }^{\mathrm{T}}$, Frigoribacterium faeni has a cell-wall peptidoglycan with lysine as the diagnostic diamino acid and MK-9 as the major menaquinone (Kämpfer et al., 2000), while Rathayibacter possesses a cell-wall peptidoglycan with 2,4diaminobutyric acid and does not contain MK-11 as the second major menaquinone (Zgurskaya et al., 1993). The isolate differs from members of the six genera (Agreia, Curtobacterium, Gulosibacter, Microbacterium, Rhodoglobus and Salinibacterium) with ornithine in the cell-wall peptidoglycan mainly based on the amino acid composition of this polymer and/or the menaquinone system (Table 1). Other characteristics useful for the differentiation of strain $\mathrm{KSW} 2-17^{\mathrm{T}}$ and related genera are given in Table 1. Members of the remaining genera of the family Microbacteriaceae have the cell-wall peptidoglycan based upon 2,4-diaminobutyric acid or lysine.

It is apparent from the genotypic and phenotypic evidence presented that strain KSW2-17 ${ }^{\mathrm{T}}$ represents a novel species of a new genus in the family Microbacteriaceae, for which the name Labedella gwakjiensis gen. nov., sp. nov. is proposed.

\section{Description of Labedella gen. nov.}

Labedella (La.be.del'la. N.L. fem. n. Labedella named in honour of David P. Labeda, who has made significant contributions to the area of actinomycete taxonomy).

Aerobic, Gram-positive, catalase-positive, oxidase-negative, non-spore-forming, non-motile, rod-shaped cells. Branching or mycelium formation does not occur. Vshaped forms are not found. Mesophilic. Chemoheterotrophic. The predominant menaquinones are MK-10 and MK-11. Peptidoglycan in the cell wall contains ornithine as 
Table 1. Differential characteristics between strain $\mathrm{KSW} 2-17^{\top}$ and related genera in the family Microbacteriaceae

Taxa: 1, strain KSW2-17 ${ }^{\mathrm{T}}$; 2, Agreia; 3, Cryobacterium; 4, Curtobacterium; 5, Frigoribacterium; 6. Gulosibacter; 7, Microbacterium; 8, Rathayibacter; 9, Rhodoglobus; 10, Salinibacterium. Data from Evtushenko et al. (2001), Suzuki et al. (1997), Komagata \& Suzuki (1986), Kämpfer et al. (2000), Manaia et al. (2004), Behrendt et al. (2002), Zgurskaya et al. (1993), Sheridan et al. (2003), Han et al. (2003) and this study. +, Positive; -, negative; DAB, 2,4-diaminobutyric acid; Lys, lysine; Orn, D-ornithine; ND, not detected.

\begin{tabular}{|lcccccccccc|}
\hline Characteristic & $\mathbf{1}$ & $\mathbf{2}$ & $\mathbf{3}$ & $\mathbf{4}$ & $\mathbf{5}$ & $\mathbf{6}$ & $\mathbf{7}$ & $\mathbf{8}$ & $\mathbf{9}$ & $\mathbf{1 0}$ \\
\hline Diamino acid & Orn & DAB, Orn & DAB & Orn & Lys & Orn & Orn, Lys & DAB & Orn & Lys, Orn \\
Major menaquinones (MK) & 10,11 & 10 & 10 & 9 & 9 & 9 & $11,12,13$, & 10 & 11,12 & 11 \\
& & & & & & & 14 & $65-72$ & $63-72$ & 62 \\
DNA G+C content (mol\%) & 68 & 67 & 65 & $68-75$ & 71.7 & 65 & 61 \\
Motility & - & + & - &,+- & + & - &,+- & - & ND \\
Optimal temperature $\left({ }^{\circ} \mathrm{C}\right)$ & $25-30$ & 28 & $9-12$ & 28 & $4-10$ & $35-37$ & 28 & 28 & 18 & $25-28$ \\
\hline
\end{tabular}

the diagnostic amino acid. The acyl type of murein is acetyl. Polar lipids contain phosphatidylglycerol and diphosphatidylglycerol. Mycolic acids are not present. The cellular fatty acid profile is characterized by the predominance of iso- and anteiso-branched components, together with a small amount of tuberculostearic acid (10methyl $\mathrm{C}_{18: 0}$ ). Phylogenetically, the genus belongs to the family Microbacteriaceae, suborder Micrococcineae. The type species is Labedella gwakjiensis.

\section{Description of Labedella gwakjiensis sp. nov.}

Labedella gwakjiensis (gwak.ji.en'sis. N.L. fem. adj. gwakjiensis pertaining to Gwakji Beach, Jeju, Republic of Korea, from where the type strain was isolated).

Has the following characteristics in addition to those given for the genus. Cells are 1.0-4.4 $\mu \mathrm{m}$ in length and 0.30 $0.38 \mu \mathrm{m}$ in width. On TSA, colonies are smooth, circular, convex, translucent and yellow-pigmented. Growth occurs between 10 and $37{ }^{\circ} \mathrm{C}$. No growth occurs at 4 or $45^{\circ} \mathrm{C}$. The $\mathrm{pH}$ range for growth is $\mathrm{pH}$ 5.1-10.1, with optimum growth at $\mathrm{pH}$ 7.1. Growth occurs in the presence of up to $5 \%$ $\mathrm{NaCl}$. Positive for $\beta$-galactosidase but negative for urease. Nitrate is not reduced to nitrite. Hydrolyses aesculin, DNA and starch. Casein and elastin are not hydrolysed. $\mathrm{H}_{2} \mathrm{~S}$ production is observed. Positive for hydrolysis of gelatin, but negative for indole production, glucose fermentation and arginine dihydrolase (API 20NE). D-Glucose, Darabinose, D-mannose, D-mannitol and $\mathrm{N}$-acetyl-D-glucosamine are utilized as sole carbon and energy sources but utilization of maltose, gluconate, caproate, adipate, malate, citrate and phenylacetate is not observed (API 20NE). Under aerobic conditions, acid is produced from Larabinose, D-cellobiose, D-fructose, D-galactose, D-glucose, inulin, D-mannose, D-melezitose, methyl $\alpha$-D-mannoside, D-raffinose, L-rhamnose, salicin, sucrose, D-xylose, glycerol, myo-inositol, D-mannitol and D-sorbitol. Acid is not produced from D-arabinose, melibiose, L-ribose, L-sorbose, adonitol, 2,3-butanediol, dulcitol, myo-erythritol, 1,2propanediol or D-xylitol. Acid is weakly produced from D-lactose, maltose, methyl $\alpha$-D-glucoside and trehalose. In the tests with the API ZYM system, positive for leucine arylamidase, $\alpha$-galactosidase, $\alpha$-glucosidase and $\beta$-glucosidase. Weakly positive for esterase lipase (C8) but negative for alkaline phosphatase, esterase (C4), lipase (C14), valine arylamidase, cystine arylamidase, trypsin, $\alpha$-chymotrypsin, acid phosphatase, naphthol-AS-BI-phosphohydrolase, $\beta$ glucuronidase, $N$-acetyl- $\alpha$-glucosaminidase, $\alpha$-mannosidase and $\alpha$-fucosidase. Major cellular fatty acids are anteiso- $\mathrm{C}_{15: 0}(49.4 \%)$, iso- $\mathrm{C}_{16: 0}(20.5 \%)$ and anteiso$\mathrm{C}_{17: 0}(11.4 \%)$. Tuberculostearic acid (10-methyl $\mathrm{C}_{18: 0}$ ) is also present as a minor component. Polar lipids contain phosphatidylglycerol and diphosphatidylglycerol. The DNA $\mathrm{G}+\mathrm{C}$ content is $68.0 \mathrm{~mol} \%$.

The type strain, KSW2-17 ${ }^{\mathrm{T}} \quad\left(=\mathrm{JCM} \quad 14008^{\mathrm{T}}=\mathrm{KCTC}\right.$ $\left.19176^{\mathrm{T}}\right)$, was isolated from a dried seaweed sample collected around Gwakji Beach in Jeju, Korea.

\section{Note added in proof}

An additional new genus, Yonghaparkia, with cell-wall peptidoglycan based on D-glutamate-D-diaminobutyric acid (Yoon et al., 2006), and the species Microcella alkaliphila containing D-ornithine in the cell wall (Tiago et al., 2006) have been described since this article was submitted for publication.

\section{Acknowledgements}

This work was supported by the 21C Frontier Microbial Genomics and Application Center Program, Ministry of Science \& Technology, Republic of Korea. I am indebted to Dong Wan Lee for analysis of cell-wall amino acids and Jin Mi Lee for isolation of the novel strain.

\section{References}

Behrendt, U., Ulrich, A., Schumann, P., Naumann, D. \& Suzuki, K. (2002). Diversity of grass-associated Microbacteriaceae isolated from the phyllosphere and litter layer after mulching the sward; a polyphasic characterization of Subtercola pratensis sp. nov., Curtobacterium herbarum sp. nov. and Plantibacter flavus gen. nov., sp. nov. Int J Syst Evol Microbiol 52, 1441-1454.

Evtushenko, L. I. \& Takeuchi, M. (2003). The family Microbacteriaceae. In The Prokaryotes: a Handbook on the Biology of 
Bacteria, 3rd edn, vol. 3, pp. 1020-1098. Edited by M. Dworkin, S. Falkow, E. Rosenberg, K. H. Schleifer \& E. Stackebrandt. New York: Springer.

Evtushenko, L. I., Dorofeeva, L. V., Dobrovolskaya, T. G., Streshinskaya, G. M., Subbotin, S. A. \& Tiedje, J. M. (2001). Agreia bicolorata gen. nov., sp. nov., to accommodate actinobacteria isolated from narrow reed grass infected by the nematode Heteroanguina graminophila. Int J Syst Evol Microbiol 51, 2073-2079.

Felsenstein, J. (1981). Evolutionary trees from DNA sequences: a maximum likelihood approach. J Mol Evol 17, 368-376.

Felsenstein, J. (1985). Confidence limits on phylogenies: an approach using the bootstrap. Evolution 39, 783-791.

Fitch, W. M. (1971). Towards defining the course of evolution: minimum change for a specific tree topology. Syst Zool 20, 406-416.

Gosink, J. J., Woese, C. R. \& Staley, J. T. (1998). Polaribacter gen. nov., with three new species, $P$. irgensii sp. nov., $P$. franzmannii sp. nov., $P$. filamentus sp. nov., gas vacuolated polar marine bacteria of the Cytophaga-Flavobacterium-Bacteroides group and reclassification of 'Flectobacillus glomeratus' as Polaribacter glomeratus comb. nov. Int J Syst Bacteriol 48, 223-235.

Han, S. K., Nedashkovskaya, O. I., Mikhailov, V. V., Kim, S. B. \& Bae, K. S. (2003). Salinibacterium amurskyense gen. nov., sp. nov., a novel genus of the family Microbacteriaceae from the marine environment. Int J Syst Evol Microbiol 53, 2061-2066.

Hancock, I. C. (1994). Analysis of cell wall constituents of Grampositive bacteria. In Chemical Methods in Prokaryotic Systematics, pp. 63-84. Edited by M. Goodfellow \& A. G. O’Donnell. Chichester: John Wiley \& Sons.

Hopwood, D. A., Bibb, M. J., Chater, K. F., Kieser, H. M., Lydiate, D. J., Smith, C. P., Ward, J. M. \& Schrempf, H. (1985). Genetic Manipulation of Streptomyces. A Laboratory Manual. Norwich: John Innes Foundation.

Inoue, K. \& Komagata, K. (1976). Taxonomic study on obligately psychrophilic bacteria isolated from Antarctica. J Gen Appl Microbiol 22, 165-176.

Jukes, T. H. \& Cantor, C. R. (1969). Evolution of protein molecules. In Mammalian Protein Metabolism, vol. 3, pp. 21-132. Edited by H. N. Munro. New York: Academic Press.

Kämpfer, P., Rainey, F. A., Andersson, M. A., Nurmiaho Lassila, E.-L., Ulrych, U., Busse, H.-J., Weiss, N., Mikkola, R. \& Salkinoja-Salonen, M. (2000). Frigoribacterium faeni gen. nov., sp. nov., a novel psychrophilic genus of the family Microbacteriaceae. Int J Syst Evol Microbiol 50, 355-363.

Komagata, K. \& Suzuki, K.-I. (1986). Genus Curtobacterium Yamada and Komagata $1972425^{\mathrm{AL}}$. In Bergey's Manual of Systematic Bacteriology, vol. 2, pp. 1313-1317. Edited by P. H. A. Sneath, N. S. Mair, M. E. Sharpe \& J. G. Holt. Baltimore: Williams and Wilkins.

Kroppenstedt, R. M. (1985). Fatty acid and menaquinone analysis of actinomycetes and related organisms. In Chemical Methods in Bacterial Systematics, pp. 173-199. Edited by M. Goodfellow \& D. E. Minnikin. London: Academic Press.

Lee, S. D. (2006). Phycicoccus jejuensis gen. nov., sp. nov., an actinomycete isolated from seaweed. Int J Syst Evol Microbiol 56, 2369-2373.

Mac Faddin, J. F. (1980). Biochemical Tests for Identification of Medical Bacteria, 2nd edn. Baltimore: Williams \& Wilkins.

Manaia, C. M., Nogles, B., Weiss, N. \& Nunes, O. C. (2004), Gulosibacter molinativorax gen. nov., sp. nov., a molinate-degrading bacterium, and classification of 'Brevibacterium helvolum' DSM 20419 as Pseudoclavibacter helvolus gen. nov., sp. nov. Int J Syst Evol Microbiol 54, 783-789.

Mesbah, M., Premachandran, U. \& Whitman, W. B. (1989). Precise measurement of the $\mathrm{G}+\mathrm{C}$ content of deoxyribonucleic acid by highperformance liquid chromatography. Int J Syst Bacteriol 39, 159-167.

Minnikin, D. E., Alshamaony, L. \& Goodfellow, M. (1977). Differentiation of Mycobacterium, Nocardia, and related taxa by thin layer chromatographic analysis of whole-cell methanolysates. J Gen Microbiol 88, 200-204.

Minnikin, D. E., O’Donnell, A. G., Goodfellow, M., Alderson, G., Athalye, M., Schaal, A. \& Parlett, J. H. (1984). An integrated procedure for the extraction of bacterial isoprenoid quinones and polar lipids. J Microbiol Methods 2, 233-241.

Park, Y. H., Suzuki, K., Yim, D. G., Lee, K. C., Kim, E., Yoon, J., Kim, S., Kho, Y. H., Goodfellow, M. \& Komagata, K. (1993). Suprageneric classification of peptidoglycan group B actinomycetes by nucleotide sequencing of 5S ribosomal RNA. Antonie van Leeuwenhoek 94, 307-313.

Saitou, N. \& Nei, M. (1987). The neighbor-joining method: a new method for reconstructing phylogenetic trees. Mol Biol Evol 4, 406-425.

Sheridan, P. P., Loveland-Curtze, J., Miteva, V. I. \& Brenchley, J. E. (2003). Rhodoglobus vestalii gen. nov., sp. nov., a novel psychrophilic organism isolated from an Antarctic Dry Valley lake. Int J Syst Evol Microbiol 53, 985-994.

Shirling, E. B. \& Gottlieb, D. (1966). Methods for characterization of Streptomyces species. Int J Syst Bacteriol 16, 313-340.

Stackebrandt, E., Rainey, F. A. \& Ward-Rainey, N. L. (1997). Proposal for a new hierarchic classification system, Actinobacteria classis nov. Int J Syst Bacteriol 47, 479-491.

Suzuki, K., Sasaki, J., Uramoto, M., Nakase, T. \& Komagata, K. (1997). Cryobacterium psychrophilum gen. nov., sp. nov., nom. rev., comb. nov., an obligately psychrophilic actinomycete to accommodate "Curtobacterium psychrophilum" Inoue and Komagata 1976. Int J Syst Bacteriol 47, 474-478.

Thompson, J. D., Gibson, T. J., Plewniak, F., Jeanmougin, F. \& Higgins, D. G. (1997). The CLUSTAL_X windows interface: flexible strategies for multiple sequence alignment aided by quality analysis tools. Nucleic Acids Res 25, 4876-4882.

Tiago, I., Pires, C., Mendes, V., Morais, P. V., Costa, M. \& Verissimo, A. (2005). Microcella putealis gen. nov., sp. nov., a Gram-positive alkaliphilic bacterium isolated from a nonsaline alkaline groundwater. Syst Appl Microbiol 28, 479-487.

Tiago, I., Morais, P., Costa, M. \& Veríssimo, A. (2006). Microcella alkaliphila sp. nov., a novel member of the family Microbacteriaceae isolated from a non-saline alkaline groundwater, and emended description of the genus Microcella. Int J Syst Evol Microbiol 56, 2313-2316

Uchida, K. \& Aida, K. (1984). An improved method for the glycolate test for simple identification of the acyl type of bacterial cell walls. J Gen Appl Microbiol 30, 131-134.

Yoon, J. H., Kang, S. J., Schumann, P. \& Oh, T. K. (2006). Yonghaparkia alkaliphila gen. nov., sp. nov., a novel member of the family Microbacteriaceae isolated from an alkaline soil. Int J Syst Evol Microbiol 56, 2415-2420.

Zgurskaya, H. I., Evtushenko, L. I., Akimov, V. N. \& Kakakoutskii, L. V. (1993). Rathayibacter gen. nov., including the species Rathayibacter rathayi comb. nov., Rathayibacter tritici comb. nov., Rathayibacter iranicus comb. nov., and six strains from annual grasses. Int J Syst Bacteriol 43, 143-149. 